\title{
The Role of Teachers' Self- and Collective-Efficacy Beliefs on Their Job Satisfaction and Experienced Emotions in School
}

\author{
Georgia Stephanou ${ }^{1}$, Georgios Gkavras ${ }^{2}$, Maria Doulkeridou ${ }^{1}$ \\ ${ }^{1}$ Department of Early Childhood Education, University of Western Macedonia, Florina, Greece \\ ${ }^{2}$ Department of Primary School Education, University of Western Macedonia, Florina, Greece \\ Email: gstephanou@uowm.gr, egokesy1@otenet.gr
}

Received December $13^{\text {th }}, 2012$; revised January $12^{\text {th }}, 2013$; accepted February $11^{\text {th }}, 2013$

\begin{abstract}
This study aimed at investigating a) teachers' job satisfaction, experienced emotions at school, self-efficacy and school collective-efficacy beliefs; b) the influential role of self-efficacy in the school collectiveefficacy beliefs, and in the impact of the school collective-efficacy beliefs on job satisfaction and emotions; and c) the effect of self- and collective-efficacy beliefs on the impact of job satisfaction on emotions. The sample comprised 268 elementary school teachers (113 male, 155 female), who completed the scales at the middle of a school year. The results showed that a) the teachers experienced form moderate negative emotions to moderate positive emotions at school, particularly in the context-task- and self-related emotions; b) teachers' self-efficacy had positive effect on school collective-efficacy beliefs and job satisfaction, and on the impact of collective efficacy on job satisfaction; c) self-efficacy, collective efficacy and job satisfaction, as a group, explained from a small to moderate amount of the variance of the emotions, while the impact of job satisfaction on the emotions was to a significant extent mediated by teachers' perceptions about their school collective efficacy; and d) self-efficacy had direct and indirect effect, through the interaction of collective efficacy and job satisfaction, on the emotions. The findings are discussed for their applications in educational practice and future research.
\end{abstract}

Keywords: Collective-Efficacy; Emotions; Job Satisfaction; Self-Efficacy

\section{Introduction}

A teacher has to regulate his/her cognitive, emotional and motivational processes in various situations that are related to his/her professional career (Boekaerts \& Corno, 2005; Carson \& Templin, 2007; Efklides \& Volet, 2005; Hargreaves, 1998; Sutton, 2004; Sutton \& Wheatley, 2003). However, although recent research on teachers' cognition, beliefs and conceptions about themselves has grown and expanded, the area remains unexplored (Hoy, Davis, \& Pape, 2006). More precisely, there is little research in practicing teachers, particularly in elementary school, about how teaches' cognition, such as efficacy beliefs, relate to their emotional experiences at school, the relationship between teachers' emotions and motivation, and how integral the interactive effects of these three concepts are in teacher development (Hoy et al., 2006; Reyna \& Weiner, 2001; Stephanou \& Mastora, submitted; Stephanou \& Sivropoulou, 2008; Stephanou \& Tsapakidou, 2007a; Sutton \& MudreyCamino, 2003). In addition, although the teachers' professsional role is context-related and socially-constructed, previous investigations have hardly examined the importance of teachers' beliefs about the conjoint capability of their school faculty, that is collective efficacy, for their well-being and achievement, and for students' academic development (Caprara, Barbaranelli, Borgogni, Petitta, \& Rubinacci, 2003; Caprara, Barbaranelli, Borgogni, \& Steca, 2003; Goddard, Hoy, \& Woolfolk Hoy, 2004; Tschannen-Moran \& Barr, 2004; Wheatley, 2005). Furthermore, while the role of both self-efficacy and collectiveefficacy beliefs on organizational and group performance is relatively well established, their covariation on teachers' well being, emotional experience and job satisfaction has much less examined (Capraca et al., 2003; Fernandez-Ballesteros, DiezNicolas, Capraca, Barbananelli, \& Bandura, 2002; Labone, 2004; Ross, 1998; Stajkovic \& Lee, 2002).

Accordantly, this study focused on the role of elementary school teachers' self-efficacy and collective efficacy beliefs on their job satisfaction and experienced emotions at school.

\section{Efficacy Beliefs and Effects on Job Satisfaction}

One important self-referenced belief for teaching is a sense of efficacy. The model of teacher efficacy by Tschannen-Moran, Woolfolk Hoy, \& Hoy (1998), conceptualizing Bandura's (1997) theory of efficacy, defines "teacher efficacy is the teacher's belief in his or her capability to organize and execute the courses of action required to successfully accomplish a specific teaching task in a particular context" (p. 232).

A strong sense of self-efficacy supports a significant advantage in initial task engagement, motivation, effort, and resilience in front of the difficulties related to teaching career. Teachers' self-efficacy positively influences their own behavior and motivation, and student achievement (Coladarci, 1992; Goddard \& Goddard, 2001; Pintrich \& Schunk, 2002; Skaalvik \& Skaalvik, 2007; Tschannen-Moran \& Johnson, 2011). For example, teachers with high self-efficacy evince greater control over the teaching/learning process (Caprara, Barbaranelli, Borgogni, Petitta et al., 2003; Jesus \& Lens, 2005; TschannenMoran \& Woolfolk Hoy, 2001). In turn, the synthesis of this 
high control expectations over the teaching/learning process and high efficacy expectations contributes in their high success expectations, which is positively related to their own future success (Jesus \& Lens, 2005). Teachers' self-efficacy is also affects teaching (Coladarci, 1992). For instance, high self-efficacious teachers, in comparison to low self-efficacious teachers, are more likely to use new curriculum materials, to change instructional strategies, and to use multiple and different teaching styles in their classes to better meet the needs of their students (Caprara, Barbaranelli, Steca, \& Malone, 2006; Kulinna \& Cothran, 2003; Stephanou \& Tsapakidou, 2007b; TschannenMoran, Woolfolk Hoy \& Hoy, 1998). Other studies have documented that teachers with high self-efficacy are more enthusiastic for teaching, are open to new ideas and are willing to test various teaching methods to satisfy their students' needs (Allinder, 1994; Ross \& Gray, 2006). Yet, teachers' self-efficacy positively influences intrinsic interest, self-satisfaction and job satisfaction (Caprara et al., 2003; Caprara, et al., 2006; Klassen, Bong, Usher, Chong, Huan, Wong, \& Georgiou, 2009; Zimmerman \& Kitsantas, 1999).

However, as previous researches (e.g., Caprara et al., 2003; Hoy \& Miskel, 2008), in consistency with Bandura's (1982, 1997, 2006) social cognitive theory, suggest, teachers' selfefficacy beliefs may not sufficient to ensure success and attain satisfaction. Rather, achievement is also influenced by the teachers' beliefs about the school, as a whole, capacity; that is the collective efficacy beliefs (Bandura, 1997; Goddard, LoGerfo, \& Hoy, 2004). Collective efficacy is "the perceptions of teachers in a school that the faculty as a whole can organize and execute the courses of action required to have a positive effect on students: (Hoy et al., 2006: p. 728).

Like self-efficacy, the findings from research in collective efficacy in various settings, including work, socio-police and school, show that the stronger the individuals' perceived collective efficacy, the stronger the persistency in the face of impediments and difficulties, the higher the outcome expectations and motivation in pursuing the goals, the higher the resilience to stressors, and the higher their performance accomplishments (see Bandura, 2000; Caprara et al., 2003; Klassen \& Chiu, 2010; Klassen, Usher, \& Bong, in press). Higher school collective efficacy also is related to higher rates of parental involvement and teacher innovation (Hoy \& Miskel, 2008; Klassen et al., in press). Yet, a strong sense of school group capacity has positive effects on student achievement, particularly for children at risk (Goddard, Hoy, \& Woolfolk Hoy, 2000; Goddard et al., 2004; Ross, 1995, 1998; Tschannen-Moran \& Barr, 2004; Woolfolk Hoy \& Davis, 2005).

Perceived group collective efficacy is influenced by its members' personal efficacy, while, in turn, the shared sense of collective efficacy may have effects on self-efficacy (Bandura, 1997; Caprara et al., 2003). As Bandura (1982) proposed 'Collective efficacy is rooted in self-efficacy. Inveterate self doubters are not easily forged into a collective efficacious force' ( $p$. 143). Accordantly, this study, based on Bandura's theory of efficacy beliefs, and Caprara, Borgogni, Barbaranelli, \& Rubinacci's (1999) model, considers the teachers' self-efficacy as an influential factor of collective efficacy and as the main significant determinant of job satisfaction, since self-efficacious teachers manage class discipline, promote learning and cooperate effectively with families and colleagues, and they are able to create and maintain situations from which they derive others' recognition and intrinsic rewards (Schmitz \& Schwarzer, 1999; Skaalvik \& Bong, 2005). But, because the capacity of school to fulfill its mission contributes to teachers' satisfaction, which hat they derive from their own attainments, collective school efficacy has a positive effect on teachers' job satisfaction (Caprara, Barbarelli, Borgogni, \& Pettita et al., 2003; Cockburn \& Haydn, 2004; Judge, Thoresen, Bono, \& Patton, 2001).

\section{Emotions}

Teachers may experience the whole spectrum of emotions across the various situations relevant to their professional role; therefore, emotions should be examined in any comprehensive discussion of teachers' motivation and behaviour (Astleitner, 2000; Frenzel, Goetz, Lüdtke, Pekrun, \& Sutton, 2009; Hargreaves, 2000; Lambert, Mccarthy, O’Donnell, \& Wang, 2009; Stephanou \& Mastora, submitted; Sutton \& Wheatley, 2003). Teachers may experience satisfaction, pride, enthusiasm, happiness and enjoyment for their good teaching, respectful relationships with their colleagues, warm school climate, and students' academic progress. In contrast, teachers may experience shame, hopelessness, anger, unhappiness and boredom for their unsuccessful teaching, negative relationships with their colleagues, undesirable school situations, and students' lack of academic progress.

Teachers' such emotional experience at school is considered precursor of their future behavior because it influences their self identity and motivation (Schutz \& DeCuir, 2002; Somech $\&$ Drach-Zahavy, 2000). For example, teachers, who are constantly frustrated or sad by disruptive students or ineffective administration, are less intrinsically motivated, express a lack of enthusiasm for cultivating positive relationships with their students and report becoming tolerant, and less caring (Blase, 1986.). Teachers' emotions in classes also influence cognitive information processing, quality of thinking, categorizing, strategies in pursuing the goals and self-regulation (see Boakaerts, Pintrich, \& Zeidner, 2000; Efklides \& Volet, 2005; Isen, 1993; Parrot \& Spackman, 2000). According to Sutton and Wheatley (2003), teachers who experience positive emotions might generate more teaching ideas and strategies that might contribute in developing 'broad minded coping' skills (Fredrickson, 2001: p. 223). These coping skills facilitate teachers to achieve their goals, such as teaching well and help students to learn. Yet, teachers' emotions have important consequences in judgments and behaviours (see Bless, 2003; Parrott, 2003; Weiner, 2005, 2006). For example, in experimental study contacted by Keltner, Ellsworth and Edwards (1993), angry and sad students attributed hypothetical misfortunes to the other and situational factors, respectively.

In addition, teachers' emotions in classes are a significant factor of students' motivation, behavior and well-being (Boekaerts, 2007; Davis, 2003; Furrer \& Skinner, 2003; Taxer \& Frenzel, 2012; Vauras, Salonen, Lehtinen, \& Kinnunen, 2009). For example, teachers' positive emotions positively affected the students of various grade levels regarding motivation, achievement and social behavior in classes (Turner, Midgey, Meyer, Gheen, Anderman, \& Kang, 2002; Turner, Meyer, Midgley, \& Patrick, 2003; Wentzel, 1996; Wong \& Dornbusch, 2000). In contrast, teachers' yelling made the children to feel small, ashamed, guilty, embarrassed and hurt (Thomas \& Montomery, 1998), and their negative emotions are predictors of students' development (Hamre \& Pianta, 2001). 


\section{Effects of Efficacy Beliefs on Job Satisfaction and Emotions}

Bandura (1997) has suggested that efficacy cognitions not only influence how people behave but they also elicit thought patterns and affective reactions to tasks that challenge personal capabilities (see also Pajares \& Schunk, 2005; Skaalvik \& Bong, 2005). Teachers with high self-efficacy are able to attain personal accomplishments and well-being, reduce stress, and are less vulnerable to depression, experience less negative emotions in teaching, and are more effective in meeting the needs of culturally diverse student groups (Ashton, Olejnik, \& Croker, 1982; Bandura, 1994; Greenwood, Olejnik, \& Parkay, 1990; Tucker, Porter, Reinke, Herman, Ivery, Mack, \& Jackson, 2005). Conversely, people with low self efficacy are face difficulties in commitments to the goals they choose to pursue, blame themselves for their failure, believe that things are tougher than they really are, a belief that fosters anxiety and stress as they engage in a task, are slow to recover after failures or setbacks, and easily fall victim to depression (Bandura, 1994; Fiori, Mcilvane, Brown, \& Antonucci, 2006; Muris, 2001; Pajares \& Schunk, 2005; Ross, 1998; Stephanou, 2004; Wheatley, 2005).

Also, despite the limited number of the researches on the association of collective efficacy with experienced emotions in school settings, there is evidence that, like self-efficacy, collective efficacy positively influences achievement-related emotions (see Charalabidou under Stephanou supervision; Klassen et al., in press). Furthermore, teachers' collective efficacy is expected to have indirect effects on their experienced emotions at school through self-efficacy because, as above discussed, it is influenced by self-efficacy.

Finally, the teachers, similarly with other professionals who are high satisfied with their job, are more likely to experience positive emotions (see Muthuvelayutham \& Mohanasundaram, 2012; Sy, Tram, \& O'Hara, 2006). Moreover, the impact of job satisfaction on emotions is expected to be affected by efficacy beliefs, mainly self-efficacy, since the higher, compered to less, efficacious individuals are more capable in to comprehend and to adapt their emotions, better understand the causes of the formulation of their negative emotions, such as stress, and they use effective strategies of holding the consequences of negative emotions (Bandura, 1994; Fiori et al., 2006; Muris, Schmidt, Lambrichs, \& Meesters, 2001; Skaalvik \& Bong, 2005).

\section{Aim and Hypotheses of the Study}

This study aimed at investigating a) teachers' job satisfaction, experienced emotions at school, self-efficacy and school collective-efficacy beliefs; b) the influential role of self-efficacy in collective-efficacy, and in the impact of collectiveefficacy beliefs on job satisfaction and emotions; and c) the effect of self- and collective-efficacy beliefs on the impact of job satisfaction on the emotions.

The following hypotheses were examined.

The teachers will report a rate of job satisfaction, self-efficacy, and collective efficacy of the school, as a as whole. However, no specific hypothesis is tested about the specific rate of each of the three concepts (Hypothesis 1). The teachers will experience various emotions at school but no specific hypothesis is tested about the extent of the intensity of each of the emotions (Hypothesis 2a). The teachers will mainly experience context- and task-related emotions (Hypothesis $2 \mathrm{~b}$ ). The teachers' self-efficacy will positively influence their beliefs about collective efficacy of their school (Hypothesis 3). Self-efficacy and perceived school collective efficacy will have positive effects on job satisfaction (Hypothesis 4a). Self-efficacy will be an influential determinant of the impact of school collectiveefficacy on job satisfaction (Hypothesis 4b). Teachers' selfefficacy, perceived school collective-efficacy and job satisfaction, separately, and, as a group, will positively influence their experienced emotion at school, mainly the self-, context- and future-related (Hypothesis 5a). Self-efficacy and perceived school collective-efficacy, together, will have positive effects on the impact of job satisfaction on the emotions (Hypothesis $5 b)$. In addition, self-efficacy will be an influential factor of the impact of collective efficacy on the effect of job satisfaction on the emotions (Hypothesis 5c).

\section{Method}

\section{Participants}

The participants were 268 elementary school teachers (113 men, 155 women), who were recruited from 85 state schools from various regions of Greece, representing a variety of Greek school settings. Their age ranged from 25 to 57 years, with average age of 45 years, $\mathrm{SD}=5.9$. They reported teaching experience from 3 to 27 years with balance among years of teaching experience.

\section{Measurements}

Emotions. The scale of the teachers' experienced emotions at school consisted of seventeen emotions: Happiness, pleasure, pride, encouragement, confidence, calmness, not angry-angry, flow-not flow, cheerfulness, exciting, not irritated-irritated, hope, competence, not nervousness-nervousness, anxiety, enthusiasm and not boredom-boredom. The teachers were asked to indicate the extent to which they usually experienced each of the above eighteen emotions at school during the current school year. The emotions had the form of adjectives, with the positive pole having the high score of 7 and the negative pole having the low score of 1 (e.g., happy 7654321 unhappy). The construction of the scale was based on previous similar re- searches (see Pekrun, Goetz, Frenzel, Barchfeld, \& Perry, 2011; Schutz \& DeCuir, 2002; Sutton \& Wheatley, 2003; Weiner, 2001, 2005), and it is a valid and reliable research instrument in studying experienced emotions in education in Greek population (see Stephanou, 201; Stephanou, Kariotoglou, \& Ntinas, 2011; Stephanou \& Mastora, submitted). Cronbach's alpha value was .89 .

Self-efficacy, Perceived School Collective-efficacy, Job satisfaction. The teachers' self-efficacy, perceived school collective-efficacy and job satisfaction were examined by a respective subscale which driven from Caprara et al.'s (2003) booklet. The teachers indicated the extent of their agreement with each of the item on a 7-point scale, which ranged from $1=$ strongly disagree to $7=$ strongly agree.

The teachers' self-efficacy was estimated via twelve items, which measured teachers' beliefs in their ability to handle effectively various tasks, challenges and obligations associated with their professional role in various setting and relations (e.g., "I am capable of dealing effectively with the problem behaviors of my students"). Cronbach's alpha value was .84 . 
Nine items measured teachers' beliefs that the school, as a whole, is capable to handle effectively, various demands, challenges and difficulties that are related to its institutional role. (e.g., "Our school is capable of overcoming successfully the various difficulties that may arise"). Cronbach's alpha $=.77$.

The job satisfaction scale consisted of four items (e.g., "I am fully satisfied with my job"). The construction of this subscale was based on the by Borgogni's (1999) modification of the Job Descriptive Index (Smith, Kendal, \& Hulin, 1969). In the present study Cronbach's alpha value was .73.

Personal factors. A set of questions was about the participants' personal factors (e.g., gender, teaching experience).

\section{Procedure}

Permission to participate was obtained from each sample school prior to administering the scales. The participants were provided written information about the aim of this research. The teachers individually completed the scales in a quite classroom in front of the researches during school time. To ensure that the teachers had good time to form an impression about the examined variables, data were collected at the middle of a school year. Also, in order to ensure that any relation among the tested variables was not due to procedure used, the teachers completed, first, the emotion scale, then the job satisfaction teaching scale, followed by the collective-efficacy scale, and, finally, the self-efficacy scale. The teachers were asked to choose a code name and use it on all the questionnaires to match the scales that were responded by the same teacher. The participants were assured of anonymity and confidentiality.

\section{Results}

\section{Teachers' Self-Efficacy, Collective Efficacy, Job Satisfaction and Emotions}

The presented findings in Table 1, confirming Hypothesis 1, show that the teachers' self-efficacy, collective efficacy beliefs and job satisfaction ranged from moderate to high.

The results from the repeated measures ANOVA, in which the teachers' experienced emotions at school over the school year was the within-subjects factor, revealed that the teachers experienced a variety of intensity of emotions, $F(17,251)=$ $60.84, p<.01, \eta^{2}=.78$. Specifically, inspection of the scores and standard deviation in Table 1 and the post hoc pairwise comparisons showed that the teachers experienced form moderate negative emotions to moderate positive emotions. Furthermore, competence, not boredom, pride, pleasure and happiness were the most intense positive emotions while anxiety, irritation, nervousness and non confidence were the most intense negative emotions.

These results totally and partly confirmed Hypothesis 2a and $2 \mathrm{~b}$, respectively.

\section{Effects of Self- Efficacy on Collective-Efficacy and Job Satisfaction}

The results form correlation coefficient analysis indicated that self-efficacy was positively related to collective efficacy ( $\mathrm{r}$ $=.82, p<.01)$. Furthermore, the results from bivariate regression analysis revealed that the teachers' self-efficacy had positive effect on their perceptions of collective efficacy of school, explaining $55 \%$ of the variance, $\mathrm{F}(1,266)=33.64, p<.01$, beta
Table 1.

Teachers' self-efficacy, school collective-efficacy, job satisfaction and experienced emotions at school.

\begin{tabular}{|c|c|c|}
\hline & Mean & $\mathrm{SD}$ \\
\hline Self-efficacy & 5.48 & .76 \\
\hline Collective efficacy & 5.38 & .77 \\
\hline Job satisfaction & 5.69 & .79 \\
\hline \multicolumn{3}{|l|}{ Emotions } \\
\hline Happiness & 4.86 & 1.24 \\
\hline Pleasure & 4.91 & 1.07 \\
\hline Pride & 4.92 & 1.53 \\
\hline Encouragement & 4.00 & 1.58 \\
\hline Confidence & 4.57 & 1.13 \\
\hline Calmness & 4.24 & 1.46 \\
\hline No anger - anger & 4.04 & 1.71 \\
\hline Flow & 4.62 & 1.14 \\
\hline Cheerfulness & 4.80 & 1.33 \\
\hline Exciting & 4.18 & 1.71 \\
\hline No irritation-irritation & 3.77 & 1.85 \\
\hline Hope & 4.27 & 1.58 \\
\hline Competence & 5.02 & 1.33 \\
\hline No nervousness-nervousness & 3.78 & 1.77 \\
\hline No anxiety-anxiety & 3.66 & 1.70 \\
\hline Enthusiasm & 4.77 & 1.45 \\
\hline Not boredom-boredom & 4.97 & 1.52 \\
\hline
\end{tabular}

$=.74, \mathrm{t}=18.37, p<.01$. These findings confirmed Hypothesis 3.

The results form correlation coefficient analyses showed that the higher the self $(\mathrm{r}=.77, p<.01)$ - and collective $(\mathrm{r}=.65, p$ $<.01$ )-efficacy, the higher the job satisfaction. In addition, the findings from hierarchical regression analysis, in which the teachers' job satisfaction was the predicted variable, and their self-efficacy (entering into second step of the analysis) and school collective-efficacy (entering into first step of the analysis) were the predictor variables (Table 2), showed that a) self-efficacy and collective efficacy, together, positively influenced job satisfaction, accounting $59 \%$ of the variance; b) collective efficacy and, mainly, self-efficacy contributed into generation of job satisfaction; and c) self-efficacy had direct effect on job satisfaction beyond that of collective efficacy, $\mathrm{R}^{2} \mathrm{ch}=.16$.

Thus, Hypotheses $4 \mathrm{a}$ and $4 \mathrm{~b}$ were in the main confirmed.

\section{The Role of Self-Efficacy and Collective-Efficacy in the Impact of Job Satisfaction on Emotions}

A series of hierarchical regression analyses, with enter method, were conducted, in which each of the teachers' experienced emotions at school over the school year was the predicted variable, and self-efficacy, collective efficacy and job satisfaction were the predictive variables. Self-efficacy, collective efficacy and job satisfaction were entered into third, sec- 
Table 2.

Results from hierarchical regression analyses for the effect of teachers' self-efficacy on the impact of their school collective-efficacy beliefs on job satisfaction.

\begin{tabular}{cccccccc}
\hline & Step & $\mathrm{R}^{2} \mathrm{ch}$ & $\mathrm{R}^{2}$ & $\mathrm{~F}(\mathrm{df})$ & $\mathrm{Fch}(\mathrm{df})$ & beta & $\mathrm{t}$ \\
\hline $\mathrm{CE}$ & $1 \mathrm{st}$ & .43 & .43 & $109(1,266)$ & $109(1,266)$ & .21 & 3.63 \\
$\mathrm{SE}$ & 2nd & .16 & .59 & $136(2,265)$ & $122(1,265)$ & .59 & 10.16
\end{tabular}

Note: All F-, Fch- and t- values, $p<.01$; CE: Collective efficacy; SE: Self- efficacy.

ond and first step of the analysis, respectively. These analyses revealed the following results.

The three concepts, as a group, explained from a small to moderate amount of the variance of the emotions, $\mathrm{R}^{2}$ ranged form .09 to .35 , and mainly accounted in the variance in the emotions of happiness $\left(\mathrm{R}^{2}=.27\right)$, confidence $\left(\mathrm{R}^{2}=.31\right)$, hope $\left(\mathrm{R}^{2}=.24\right)$, flow $\left(\mathrm{R}^{2}=.35\right)$ and no boredom-boredom $\left(\mathrm{R}^{2}\right.$ $=.19)$.

Also, the impact of job satisfaction on the emotions was to a significant extent mediated by teachers' perceptions about their school collective efficacy, $\mathrm{R}^{2}$ ch ranged from .017 (exciting) to .12 (happiness).

Self-efficacy had direct, $\mathrm{R}^{2}$ ch ranged from .016 for happiness to .052 for hope, and indirect effect, through the interaction of collective efficacy and job satisfaction, on the emotions.

The teachers' self-efficacy, collective efficacy and job satisfaction were positively associated with their experienced emotions over the school year. Furthermore, the higher the teachers' self-efficacy was, the higher their perceptions of the school efficacy were and the higher their satisfaction with their job was, the more intense their positive emotions were. However, no one of the three concepts was correlated to the emotion of nervousness, while job satisfaction was not associated with the emotions of pleasure, encouragement, calmness, no anger-anger and competence.

Also, while the efficacy beliefs and job satisfaction accounted in the variance in the emotional experience, their relative power in influencing emotions differed across the emotions and within each emotion. More precisely, self-efficacy, compared to both collective efficacy and job satisfaction, was the most powerful formulator of most of the emotions, with the exception being in the emotions of calmness and flow, which were best predicted by the perceived collective efficacy, and in the emotions of cheerfulness and anxiety, which were only predicted by job satisfaction. On the other hand, collective efficacy, in comparison to job satisfaction, was a more powerful determinant of the emotions, expect of the emotion of no boredom-boredom, into which collective efficacy had no significant contribution.

Also, self-efficacy best predicted the emotions of hope, confidence, no irritation- irritation, no boredom-boredom, happiness, pleasure and encouragement than it did in the rest of the emotions. Collective efficacy was a more powerful formulator of the emotions of flow, confidence, excitement, no irritationirritation, happiness and encouragement than of the rest of the emotions. Finally, the emotions of confidence, hope, happiness, no irritation-irritation and excitement, as compared to the other emotions were better predicted by job satisfaction.

Hypotheses $5 \mathrm{a}, 5 \mathrm{~b}$ and $5 \mathrm{c}$ were in the main confirmed by the above results.

\section{Discussion}

This study focused on the relationship of teachers' self- and collective-efficacy beliefs with their job satisfaction and experienced emotions at school. The results in the main confirmed our hypotheses and previous research evidence.

\section{Efficacy Beliefs and Job Satisfaction}

The findings from the present study, supporting previous research evidence (e.g., Klassen et al., in press; Wolters \& Daugherty, 2007), revealed that the elementary school teachers had from moderate to high self-efficacy and collective efficacy beliefs, and they were satisfied with their job. It seems that the participants worked in supportive school climate, with cooperative colleagues and parents, and with children making progress (Betoret, 2006; Caprara, Barbaranelli, Borgogni, \& Petitta et al., 2003; Cockburn \& Haydn, 2004; Goddard \& LoGerfo, et al., 2004; Schwarzer \& Hallum, 2008; Skaalvik \& Skaalvik, 2007). These findings are in contrast to other studies which show that teachers in higher grade levels reported lower self-efficacy and job satisfaction than teachers in lower grade (see Klassen \& Chiu, 2010). Research should examine how school level and context influence teachers' efficacy beliefs and job satisfaction.

Also, in consistency with previous researches (e.g., Hackman et al., 2000; Caprara et al., 2003; Caprara et al., 2006; Klassen \& Chiu, 2010; Tschannen-Moran \& Woolfolk Hoy, 2001), teachers' self efficacy beliefs appeared to be a significant determinant of the formulation of their collective efficacy beliefs and job satisfaction. Furthermore, teachers' self-efficacy had positive effects on their perceptions of school collective efficacy, which, in turn, influenced teachers' job satisfaction. This specific finding suggests, in agreement with other researches (e.g., Klassen et al., in press), that not teachers' self-efficacy and collective efficacy influence job satisfaction in the same way and extent.

\section{Emotions}

Confirming in the main our predictions, the teachers experienced a variation of intensity of emotions at their school, underlying the high importance of their professional role in their self-identity, since under high ego involvement conditions individuals feel such emotional pattern (Frijda, 2009; Lambert et al., 2009; Roseman \& Smith, 2001; Stephanou, 2011; Stephanou et al., 2011; Stephanou \& Tsapakidou, 2007a; Sutton \& Wheatley, 2003; Weiner, 2001, 2005). The teachers' distinct professional role in their whole life was also supported by the nature of the reported emotions, based on Seligman's (2002) view of classification of emotions. Specifically, they considered the development of their professional life, by experiencing emotions which are related to the past (e.g., pride/shame), the present (e.g., pleasure/displeasure) and the future (e.g., confidence/non confidence, hope/ hopelessness).

The teachers' variation of the experienced emotions in school, in addition, reflects the respective variation of the sources. Furt hermore, the teachers mainly felt intense context (not boredom)-, task (pleasure)- and self (competence, pride)-related positive emotions, stressing the influential role of the context and self beliefs in it, in consistency with previous studies (Frijda, 2009; Pekrun \& Stephens, 2009; Sutton \& Wheatley, 2003). The teachers, on the other hand, experienced more intense the 
Table 3.

Results from hierarchical regression analyses for the effect of teachers' self-efficacy on the impact of collective efficacy on the effect of job satisfaction on the emotions.

\begin{tabular}{|c|c|c|c|c|c|c|c|c|}
\hline Emotions & & Steps & $\mathrm{R}^{2}$ & $\mathrm{R}^{2} \mathrm{ch}$ & $\mathrm{F}$ & Fch & beta & $\mathrm{t}$ \\
\hline \multirow{3}{*}{ Happiness } & Job satisfaction & 1 st & .13 & & 42.43 & & .22 & 9.55 \\
\hline & Collective efficacy & 2 nd & .26 & .124 & 46.82 & 44.35 & .37 & 4.59 \\
\hline & Self-efficacy & $3 \mathrm{rd}$ & .27 & .016 & 33.72 & 5.81 & .54 & 2.41 \\
\hline \multirow{3}{*}{ Pleasure } & Job satisfaction & $1 \mathrm{st}$ & -- & & -- & & & \\
\hline & Collective efficacy & 2 nd & .12 & .12 & 18.44 & 21.87 & .25 & 2.81 \\
\hline & Self-efficacy & $3 \mathrm{rd}$ & .14 & .021 & 14.48 & 6.30 & .57 & 2.51 \\
\hline \multirow{3}{*}{ Pride } & Job satisfaction & $1 \mathrm{st}$ & .09 & .09 & 28.65 & & .19 & 5.44 \\
\hline & Collective efficacy & 2 nd & .12 & .03 & 19.57 & 9.96 & .21 & 2.30 \\
\hline & Self-efficacy & $3 \mathrm{rd}$ & .12 & -- & 13.26 & -- & .49 & 5.20 \\
\hline \multirow{3}{*}{ Encouragement } & Job satisfaction & $1 \mathrm{st}$ & -- & & -- & & & \\
\hline & Collective efficacy & 2 nd & .17 & & 27.75 & 19.89 & .36 & 4.19 \\
\hline & Self-efficacy & $3 \mathrm{rd}$ & .18 & .012 & 18.64 & 4.89 & .52 & 3.69 \\
\hline \multirow{3}{*}{ Confidence } & Job satisfaction & $1 \mathrm{st}$ & .19 & & 66.92 & & .29 & 10.55 \\
\hline & Collective efficacy & 2 nd & .28 & .087 & 55.89 & 32.68 & .48 & 3.38 \\
\hline & Self-efficacy & $3 \mathrm{rd}$ & .31 & .027 & 40.25 & 10.88 & .64 & 3.23 \\
\hline \multirow{3}{*}{ Calmness } & Job satisfaction & $1 \mathrm{st}$ & -- & & -- & & & \\
\hline & Collective efficacy & 2 nd & .10 & & 14.78 & & .19 & 1.98 \\
\hline & Self-efficacy & $3 \mathrm{rd}$ & .10 & -- & 9.61 & -- & --- & \\
\hline \multirow{3}{*}{ No anger-anger } & Job satisfaction & $1 \mathrm{st}$ & -- & & -- & & & \\
\hline & Collective efficacy & 2 nd & .07 & & 19.42 & & .31 & 5.34 \\
\hline & Self-efficacy & $3 \mathrm{rd}$ & .10 & .031 & 9.89 & 9.13 & .48 & 3.02 \\
\hline \multirow{3}{*}{ Flow } & Job satisfaction & $1 \mathrm{st}$ & .25 & & 91.82 & & .39 & 9.85 \\
\hline & Collective efficacy & 2nd & .34 & .089 & 69.98 & 35.98 & .50 & 5.15 \\
\hline & Self-efficacy & $3 \mathrm{rd}$ & .35 & -- & 46.44 & -- & --- & \\
\hline \multirow{3}{*}{ Cheerfulness } & Job satisfaction & $1 \mathrm{st}$ & .09 & & 28.48 & & .32 & 5.32 \\
\hline & Collective efficacy & 2nd & .09 & -- & 14.39 & -- & --- & \\
\hline & Self-efficacy & $3 \mathrm{rd}$ & .09 & -- & 9.65 & -- & --- & \\
\hline \multirow{3}{*}{ Exciting } & Job satisfaction & $1 \mathrm{st}$ & .16 & & 16.04 & & .21 & 4.99 \\
\hline & Collective efficacy & 2 nd & .17 & .017 & 27.49 & 4.96 & .43 & 5.48 \\
\hline & Self-efficacy & $3 \mathrm{rd}$ & .18 & .019 & 19.97 & 3.57 & .47 & 2.89 \\
\hline \multirow{3}{*}{ No irritation - irritation } & Job satisfaction & $1 \mathrm{st}$ & .11 & & 32.85 & & .23 & 8.02 \\
\hline & Collective efficacy & 2 nd & .14 & .039 & 23.16 & 12.14 & .40 & 2.02 \\
\hline & Self-efficacy & $3 \mathrm{rd}$ & .20 & .051 & 22.08 & 16.92 & .69 & 4.11 \\
\hline \multirow{3}{*}{ Hope } & Job satisfaction & $1 \mathrm{st}$ & .10 & & 30.95 & & .22 & 9.23 \\
\hline & Collective efficacy & 2 nd & .19 & .089 & 31.82 & 29.37 & .40 & 2.68 \\
\hline & Self-efficacy & $3 \mathrm{rd}$ & .24 & .052 & 28.64 & 18.91 & .77 & 4.26 \\
\hline \multirow{3}{*}{ Competence } & Job satisfaction & $1 \mathrm{st}$ & -- & & -- & & & \\
\hline & Collective efficacy & 2 nd & .09 & & 13.61 & & .24 & 2.71 \\
\hline & Self-efficacy & $3 \mathrm{rd}$ & .10 & .019 & 10.73 & 5.62 & .24 & 2.37 \\
\hline \multirow{3}{*}{ No nervousness- nervousness } & Job satisfaction & $1 \mathrm{st}$ & -- & & & & & \\
\hline & Collective efficacy & 2nd & -- & & & & & \\
\hline & Self-efficacy & $3 \mathrm{rd}$ & -- & & & & & \\
\hline \multirow{3}{*}{ Not anxiety - anxiety } & Job satisfaction & $1 \mathrm{st}$ & .05 & & 8.89 & & .15 & 3.37 \\
\hline & Collective efficacy & 2nd & -- & -- & -- & -- & --- & \\
\hline & Self-efficacy & $3 \mathrm{rd}$ & -- & -- & -- & -- & --- & \\
\hline \multirow{3}{*}{ Enthusiasm } & Job satisfaction & $1 \mathrm{st}$ & .07 & & 21.34 & & .18 & 3.55 \\
\hline & Collective efficacy & 2 nd & .09 & .025 & 14.47 & 7.26 & .28 & 3.23 \\
\hline & Self-efficacy & $3 \mathrm{rd}$ & .10 & .019 & 10.77 & 3.89 & .32 & 1.97 \\
\hline \multirow{3}{*}{ Not boredom - boredom } & Job satisfaction & $1 \mathrm{st}$ & .17 & & 55.34 & & .18 & 6.63 \\
\hline & Collective efficacy & 2 nd & .17 & -- & 27.93 & -- & --- & \\
\hline & Self-efficacy & $3 \mathrm{rd}$ & .19 & .021 & 21.31 & 6.85 & .57 & 2.16 \\
\hline
\end{tabular}

Note: Only the variables that were related each other were included in the analyses; All F- and Fch-values, $p<.01 ; \mathrm{t} \leq 2.51, p<.05, \mathrm{t}>2.51, p<.01$. 
self-task (anxiety)- and other (irritation, nervousness)-related negative emotions than the rest of the emotions, indicating the determinant role of the significant others, such as school administration, students and colleagues in their well being (see Buss \& Hughes, 2007; Frenzel et al., 2009; Lambert et al., 2009; McCormick \& Barnett, 2011; Parrrott, 2003; Schutz, Hong, Cross, \& Osbon, 2006; Summers \& Davis, 2006; Yoon, 2002).

It should mentioned that high anxiety can impairs task relevant processing, such as solving the various problems that occur every day in school (Ashcraft \& Kirk, 2001; Schutz \& DeCuir, 2002). Generally, teachers' negative emotions may confront their goals and classroom management, and affect their intrinsic motivation and efficacy beliefs (see Blase, 1986; Derryberry \& Tucker, 1994; Keltner et al., 1993; Emmer, 1994).

Lack of intensive negative emotions at school may be partly explained by the participants' educational level. Probably the primary school 'caring for their students' overcome the possible children's misbehaviour and/or academic problems and, hence, in contrast to other studies in middle school (e.g., Hargreaves, 2000; Sutton, 2000), intense anger and irritation did not arise. Also, perhaps the colleagues and parents were cooperative resulting in lack of such emotions (Erb, 2002; Lasky, 2000).

\section{Effects of Efficacy Beliefs and Job Satisfaction on Emotions}

The pattern of the effect of teachers' efficacy beliefs and job satisfaction on their experienced emotions at school supports the notion that perceptions of self, task and context contribute into an emotional experience in a given school situation (Boakaerts \& Corno, 2005; Pekrun, Frenzel, Goetz, \& Perry, 2007; Pekrun, Goetz, Daniels, Stupnisky, \& Perry, 2010; Schutz \& Lenehart, 2002; Stephanou, 2011, Stephanou et al., 2011; Turner \& Schallert, 2001; Weiner, 1992, 2001). Also, the teachers might have appraised the status of self- factors in pursuing their goals that include being good in teaching and fitting the mission of their school, since emotions, such as anxiety, are experienced in relationship to goals (Carver \& Scheier, 2000; Frijda, 2005, 2009; Linnenbrink \& Pintrich, 2002; Pekrun, Maier, \& Elliot, 2009). Yet, the three concepts, as a group, mainly influenced the generation of the outcome (happiness)-, task (flow)-, future activity (not boredom)- and future behaviour (confidence, hope)-related emotions, underling their significant role in teachers' future behaviour, motivation and professional development (see Bandura, 2006; Reyna \& Weiner, 2001; Skaalvik \& Skaalvik, 2007; Sutton \& Mudrey-Camino, 2003; Tschannen-Moran \& Woolfolk Hoy, 2001).

Confirmation of higher than lower self-efficacy, collective efficacy and job satisfaction reported more intense positive emotions, except of the emotion of nervousness, which was not predicted by any of the three concepts. This specific finding addresses the necessity of clarification of the sources (and consequences) of teachers' emotions.

As expected, teachers' self-efficacy, as compared to their collective efficacy and job satisfaction, proved to be a significant advantage in their emotional experience at school, with the exception being in the emotions of calmness, flow and anxiety. More precisely, the emotions of calmness and flow were mainly formulated by collective efficacy, reflecting the contribution of the task- and context- related factors, such as administrators, parents, colleagues in school collective efficacy, and, in turn, in emotions. On the other hand, job satisfaction was the solo predictor of the emotion of anxiety, which is goal related, while it had no effect on the emotions of pleasure, encouragement, calmness, no anger and competence.

The limited role of job satisfaction on teachers' positive emotions may hind that, although teachers gain satisfaction from their job, they experience stress (the experience of negative emotions resulting from their work). This argument is supported by previous studies, documenting the major role of stress on teachers' job satisfaction (Liu \& Ramsey, 2008).

Also, self-efficacy and collective efficacy beliefs had unique and complimentarily effect on the emotions, lending further support to the earlier findings about their dinstict conceptualization (see Goddard et al., 2004).

The nature of the emotions that were best predicted by self-efficacy may be partly explained by its influential factors (Bandura, 1997, 2006; Lapone, 2004; Ross, 1998; TschannenMoran \& Johnson, 2011). Self-efficacy might have based on factors, such as ability, effort and motivation. Accordantly, it could be expected that competitive dependent-emotions, such as confidence and encouragement, and expectancy dependentemotions, such as hope, would be predicted by self-efficacy (Ross, Cousins, \& Gadalla, 1996; Weiner, 2005). The prediction of the general- and context-related emotions, such as pleasure, not irritation and no boredom, reflects the high self-efficacious' capacity in controlling their surroundings and enjoy taskinvolvement (see Bandura, 1997; Ross, 1998; Csikszentmihalyi, 1990; Pajares \& Schunk, 2005; Pekrun et al., 2010; Schmitz \& Schwarzer, 1999; Wheatley, 2005).

In a similar way, collective efficacy proved best predictor of the competitive dependent-emotions underling the teachers' perceptions of their school, as a whole, capacity as well as it was determinant formulator of the context (flow, excitement)and general (happiness)-related emotions, reflecting the ma- jor role of the school-related factors in in collective efficacy (see Caprara et al., 2003; Klassen et al., in press).

\section{Implications of the Findings in Education and Future Research}

Self efficacy was found to influence collective efficacy, while the two concepts had unique and complimentarily effect on teachers' job satisfaction and emotions. Therefore, it is essential to design teacher in-service programs that promote self-efficacy, and foster the various school constituencies that develop a robust sense of collective efficacy.

The present findings also suggest that emotional experience constitutes an important aspect of teacher's involvement at school, and, accordantly, teachers' recognition and regulation of their emotions is an essential part of effective professional life and subjective well-being. Self-factors, such as ability, motivation, effort and stress, along with school constituencies were considered as explanations of the present results. Therefore, it is interesting to examine how such factors influence the inter-correlations among the examined variables. To overcome the limitations of this study, and expand, in addition, knowledge about the considered variables, future research should be performed in various domains and academic subjects, and across teaching levels and ages.

Conclusively, investigating teachers' efficacy beliefs, along with job satisfaction and emotions, provides useful information in understanding their motivation and behaviour. 


\section{G. STEPHANOU ET AL.}

\section{REFERENCES}

Allinder, R. M. (1994). The relationship between efficacy and the instructional practice of special education teachers and consultants. Teacher Education and Special Education, 17, 86-95. doi: $10.1177 / 088840649401700203$

Ashcraft, M., H., \& Kirk, E. P. (2001). The relationshis among working memory, math anxiety, and performance. Journal of Experimental Psychology: General, 130, 224-237. doi:10.1037/0096-3445.130.2.224

Ashton, P. T., Olejnik, S., \& Croker, L. (1992). Measurment problems in the study of teachers' sense of efficacy. The Annual Meeting of the American Educational Research Association. New York.

Astleitner, H. (2000). Designing emotionally sound instruction: The FEASP-approach. Instructional Science, 28, 169-198. doi:10.1023/A:1003893915778

Bandura, A. (1994). Self-efficacy. In V. S. Ramachaudran (Ed.), Encyclopedia of human behaviour (pp. 71-81). New York: Academic Press.

Bandura, A. (1997). Self-efficacy: The exercise of control. New York: Freeman.

Bandura, A. (2006). Guide for constructing self-efficacy scales. In F. Pajares, \& T. Urdan (Eds.), Adolescence and education: Vol. 5. Self efficacy and adolescence (pp. 307-337). Greenwich, CT: Information Age.

Betoret, F. D. (2006). Stressors, self-efficacy, coping resources, and burnout among secondary school teachers in Spain. Educational Psychology, 26, 519-539. doi:10.1080/01443410500342492

Blase, J. J. (1986). A qualitative analysis of sources of teacher stress: Consequences for performance. American Educational Research Journal, 23, 13-40.

Boekaerts, M. (2007). Understanding students' affective processes in the classroom. In P. Schutz, R. Pekrun, \& G. Phye (Eds), Emotion in education (pp. 37-56). San Diego, CA: Academic Press. doi:10.1016/B978-012372545-5/50004-6

Boekaerts, M., \& Corno, L. (2005). Self-regulation in the classroom. Applied Psychology, 54, 199-231. doi:10.1111/j.1464-0597.2005.00205.x

Borgogni, L. (1999). The social-cognitive approach to the study of organizational variables. Unpublished Ph.D. Dissertation, Padova: University of Padova.

Buck, G. A., \& Cordes, J. G. (2005). An action research project on preparing teachers to meet the needs of underserved student populations. Journal of Science Teacher Education, 16, 43-64. doi:10.1007/s10972-005-6991-x

Buss, M. T., \& Hughes, J. N. (2007). Teachers' attitudes toward emotions predict implementation of and satisfaction with a social-emotional curriculum. Washington DC: Society for Prevention Research.

Caprara, G. V., Barbaranelli, C., Borgogni, I., Petitta, I., \& Rubinacci, A. (2003).Teachers', school staff's and parents' efficacy beliefs as determinants of attitude toward school. European Journal of Psychology of Education, 18, 15-31. doi:10.1007/BF03173601

Caprara, G. V., Barbaranelli, C., Borgogni, L., \& Steca, P. (2003). Efficacy beliefs as determinants of teachers' job satisfaction. Journal of Educational Psychology, 95, 821-832. doi:10.1037/0022-0663.95.4.821

Caprara, G. V., Barbaranelli, C., Steca, P., \& Malone, P. S. (2006). Teachers' self-efficacy beliefs as determinants of job satisfaction and students' academic achievement: A study at the school level. Journal of School Psychology, 44, 473-490. doi:10.1016/j.jsp.2006.09.001

Caprara, G. V., Borgogni, I., Barbaranelli, C., \& Rubinacci, A. (1999). Efficacy beliefs and organizational change. Sviluppo e Organizzazione, 174, 19-32.

Carson, R. L., \& Templin, T. J. (2007). Emotion regulation and teacher burnout: Who says that the management of emotional expression doesn't matter? American Education Research Association Annual Convention, Chicago.

Carver, C. S., \& Scheier, M. F. (2000). Scaling back goals and readibration of the affect system are processes in normal adaptive selfregulation: Understanding "response shift" phenomena. Social Science and Medicine, 50, 1715-1722. doi:10.1016/S0277-9536(99)00412-8
Cockburn, A. D., \& Haydn, T. (2004). Recruiting and retaining teachers: Understanding why teachers teach. London: Routledge Falmer. doi: $10.4324 / 9780203464854$

Coladarci, T. (1992). Teachers' sense of efficacy and commitment to teaching. Journal of Experimental Education, 60, 323-337. doi:10.1080/00220973.1992.9943869

Csikszentmihalyi, M. (1990). Flow: The psychology of optimal experience. New York: Harper Collins.

Davis, H. A. (2003). Conceptualizing the role and influence of studentteacher relationship on childern's social and cognitive development. Educational Psychologist, 38, 207-234. doi:10.1207/S15326985EP3804 2

Derryberry, D., \& Tucker, D. M. (1994). Motivating the focus of attention. In P. M. Niedenthal, \& S. Kitayama (Eds.), The hearts eye: Emotional influence in perception and attention (pp. 167-196). San Diego, CA: Academic press.

Efklides, A., \& Volet, S. (2005). Feelings and emotions in the learning process. Learning and Instruction, 15.

Emmer, E. T. (1994). Teacher emotions and classroom management. Annual Meeting of the American Educational Research Association. New Orleans, LA.

Erb, C. S. (2002). The emotional whirlpool of beginning teachers' work. The Annual Meeting of the Canandian Society of Studies in Education. Torondo.

Fernandez-Ballesteros, R., Diez-Nicolas, J., Capraca, G. V., Barbananelli, C., \& Bandura, A. (2002). Structural relation of perceived collective efficacy. Applied Psychology: An International Review, 51, 107-125. doi:10.1111/1464-0597.00081

Fiori, K. L., McIlvane, J. M., Brown, E. E., \& Antonucci, T. C. (2006). Social relations and depressive symptomatology: Self-efficacy as a mediator. Aging Mental Health, 10, 227-239. doi:10.1080/13607860500310690

Fredrickson, B. I. (2001). The role of positive emotions in positive psychology: The broaden-and-build theory of positive emotions. American Psychologist, 56, 218-226. doi:10.1037/0003-066X.56.3.218

Frenzel, A. C., Goetz, T., Lüdtke, O., Pekrun, R., \& Sutton, R. (2009). Emotional transmission in the classroom: Exploring the relationship between teacher and student enjoyment. Journal of Educational Psychology, 101, 705-716. doi:10.1037/a0014695

Frijda, N. H. (2005). Emotion experience. Cognition \& Emotion, 19, 473-498. doi:10.1080/02699930441000346

Frijda, N. H. (2009). Emotions, individual differences, and time course: Reflections. Cognition and Emotion, 23, 1444-1461.

doi:10.1080/02699930903093276

Goddard, R. D., \& Goddard, Y., L. (2001). A multilevel analysis of the relationship between teacher and collective efficacy in urban schools. Teaching and Teacher Education, 17, 807-818. doi:10.1016/S0742-051X(01)00032-4

Goddard, R. D., Hoy, W. K., \& Woolfolk Hoy, A. (2000). Collective efficacy: Its meaning, measure, and impact on student achievement. American Educational Research Journal, 37, 479-507.

Goddard, R. D., LoGerfo, I., \& Hoy, W. K. (2004). High school accountability: The role of perceived collective efficacy. Educational Policy, 18, 403-435. doi:10.1177/0895904804265066

Goddard, R. D., Hoy, W. K., \& Hoy, A. W. (2004). Collective ef- ficacy beliefs: Theoretical developments, empirical evidence, and future directions. Educational Researcher, 33, 3-13. doi: $10.3102 / 0013189 \times 033003003$

Greenwood, G., Olejnik, S., \& Parkay, F. W. (1990). Relationships between four teacher efficacy belief patterns and selected teacher characteristics. Journal of Research and Development in Education, 23, 102-106.

Hamre, B., \& Pianta, R. C. (2001). Early teacher-child relationships and trajectory of school outcomes through eighth grade. Child Development, 72, 625-638. doi:10.1111/1467-8624.00301

Hargreaves, A. (1998). The emotional practice of teaching. Teaching and Teacher Education, 14, 835-854. doi:10.1016/S0742-051X(98)00025-0

Hargreaves, A. (2000). Mixed emotions: Teachers' perceptions of their interactions with students. Teaching and Teacher Education, 16, 811-826. doi:10.1016/S0742-051X(00)00028-7 
Hoy, A. W., Davis, H., \& Pape, S. J. (2006). Teacher knowledge and beliefs. In P. A. Alexander, \& P. H. Winne (Eds.), Handbook of educational psychology (2nd Edition, pp. 715-737). Mahwah, NJ: Lawrence Erlbaum.

Hoy, W. K., \& Miskel, C. G. (2008). Educational administration: Theory, research, and practice (8th ed.). New York: McGraw-Hill.

Isen, A. M. (1993). Positive affect and decision making. In M. Lewis, \& J. M. Haviland, (Eds.), Handbook of emotions (pp. 261-277). New York: Guilford Press.

Jesus, S., \& Lens, W. (2005). An integrated model for the study of teacher motivation. Applied Psychology: An International Review, 54, 119-134. doi:10.1111/j.1464-0597.2005.00199.x

Judge, T. A., Thoresen, C. J., Bono, J. E., \& Patton, G. K. (2001). The job satisfaction-job performance relationship: A qualitative and quantitative review. Psychological Bulletin, 127, 376-407. doi:10.1037/0033-2909.127.3.376

Keltner, D., Ellsworth, P. C., \& Edwards, K. (1993). Beyond simple pessimism: Effects of sadness and anger on social judgement. Journal of Personality and Social Psychology, 64, 740-752. doi:10.1037/0022-3514.64.5.740

Klassen, R. M., Bong, M., Usher, E. L., Chong, W. H., Huan, V. S., Wong, I. Y., \& Georgiou, T. (2009). Exploring the validity of the teachers' self-efficacy scale in five countries. Contemporary Educational Psychology,34, 67-76. doi:10.1016/j.cedpsych.2008.08.001

Klassen, R. M., \& Chiu, M. M. (2010). Effects on teachers' self- efficacy and job satisfaction: Teacher gender, years of experience, and job stress. Journal of Educational Psychology, 102, 741-756. doi: $10.1037 / \mathrm{a} 0019237$

Klassen, R. M., Usher, E. L., \& Bong, M. (in press). Teachers' collective efficacy, job satisfaction, and job stress in cross-cultural context. Journal of Experimental Education.

Kulinna, P. H., \& Cothran, D. (2003). Physical education teachers' selfreported use and perceptions of various teaching styles. Learning and Instruction, 13, 597-609. doi:10.1016/S0959-4752(02)00044-0

Labone, E. (2004). Teacher efficacy: Maturing the construct through research in alternative paradigms. Teaching and Teacher Education, 20, 341-359. doi:10.1016/j.tate.2004.02.013

Lambert, L. G., McCarthy, C., O’Donnell, M., \& Wang, C. (2009). Measuring elementary teacher stress and coping in the classroom: Validity evidence for the classroom appraisal of resources, and demands. Psychology in the Schools, 46, 973-988. doi: $10.1002 /$ pits. 20438

Lasky, S. (2000). The cultural and emotional polities of teacher-parent interactions. Teaching Teacher Education, 16, 843-860. doi:10.1016/S0742-051X(00)00030-5

Liu, X. S., \& Ramsey, J. (2008). Teachers' job satisfaction: Analyses of the teacher follow-up survey in the United States for 2000-2001. Teaching and Teacher Education, 24, 1173-1184. doi:10.1016/j.tate.2006.11.010

Muthuvelayutham, C., \& Mohanasundaram, H. (2012). A study on the impact of occupational stress among teachers on job satisfaction and job involvement-An empirical study. European Journal of Social Sciences, 30, 339-351.

McCormick, J. \& Barnett, K. (2011). Teachers' attributions for stress and their relationships with burnout. International Journal of Educational Management, 25, 278-293. doi:10.1108/09513541111120114

Muris, P. (2001). Relationships between self-efficacy and symptoms of anxiety disorders and depression in a normal adolescent sample. Personality and Individual Differences, 32, 337-348. doi:10.1016/S0191-8869(01)00027-7

Muris, P., Schmidt, H., Lambrichs, R., \& Meesters, C. (2001). Protective and vulnerability factors of depression in normal adolescents. Behavior Research and Therapy, 39, 555-565. doi:10.1016/S0005-7967(00)00026-7

Pajares, F., \& Schunk, D. H. (2005). Self-efficacy and self-concept beliefs: Jointly contributing to the quality of human life. In $\mathrm{H}$. W. Marsh, R. G. Craven, \& D. M. McInerney (Eds.), International advances in self research Vol. II (pp. 95-122). Greenwich: Age Publishing.

Parrott, W. G. (2003). The nature of emotions. In A. Tesser, \& N. Schwarz (Eds.), Handbook of social psychology: Intraindividual proc- esses (pp. 375-390). Oxford: Blackwell.

Parrot, W. G., \& Spackman, M. P. (2000). Emotion and memory. In M. Lewis, \& J. M. Haviland-Jones (Eds.), Handbook of emotions (pp. 476-490). New York: Guilford Press.

Pekrun, R., Frenzel, A., Goetz, T., \& Perry, R. P. (2007). The controlvalue theory of achievement emotions: An integrative approach to emotions in education. In P. A. Schutz, \& R. Pekrun (Eds.), Emotion in education (pp. 13-36). San Diego, CA: Academic Press. doi:10.1016/B978-012372545-5/50003-4

Pekrun, R., Goetz, T., Daniels, L. M., Stupnisky, R. H., \& Perry, R. P. (2010). Boredom in achievement settings: Control-value antecedents and performance outcomes of a neglected emotion. Journal of Educational Psychology, 102, 531-549. doi:10.1037/a0019243

Pekrun, R., Goetz, T., Frenzel, A. C., Barchfeld, P., \& Perry, R. P. (2011). Measuring emotions in students' learning and performance: The achievement emotions questionnaire (AEQ). Contemporary Educational Psychology 36, 36-48. doi:10.1016/j.cedpsych.2010.10.002

Pekrun, R., Maier, M. A., \& Elliot, A. J. (2009). Achievement goals and achievement emotions: Testing a model of their relations with academic performance. Journal of Educational Psychology, 100(1), 115-135. doi:10.1037/a0013383

Pekrun, R., \& Stephens, E. J. (2009). Goals, emotions, and emotion regulation: Perspectives of the control-value theory of achievement emotions. Human Development, 52, 357-365. doi: $10.1159 / 000242349$

Pintrich, P. R., \& Schunk, D. (2002). Motivation in education: Theory, research, and applications (2nd ed.). Upper Saddle River, NJ: Prentice Hall.

Reyna, C., \& Weiner, B. (2001). Justice and utility in the classroom: An atributional analysis of the goals of teachers; punishment and intervention strategies. Journal of Educational Psychology, 93, 309319. doi:10.1037/0022-0663.93.2.309

Roseman I. J., \& Smith, C. A. (2001). Appraisal theory: Overview, assuptions, varieties, controverties. In K. R. Scherer, \& T. Johnson (Eds.), Appraisal processes in emotion: Theory, methods, research (pp. 3-18). Oxford: University Press.

Ross, J. A. (1995). The impact of an inservice to promote cooperative learning on the stability of teacher efficacy. Teacher College Record, 97, 227-252.

Ross, J. A. (1998). The antecedents and consequences of teacher efficacy. In J. Brophy (Ed.), Advances in research on teaching (Vol. 7, pp. 49-73). Greenwich, CT: JAI Press.

Ross, J. A., Cousins, J. B., \& Gadalla, T. (1996). Within-teacher predictors of teacher efficacy. Teaching and Teacher Education, 12, 385-400. doi:10.1016/0742-051X(95)00046-M

Ross. J. A., \& Gray, P. (2006). Transformational leadership and teacher commitment to organizational values: The mediating effects of collective teacher efficacy. School Effectiveness and School Improvement, 17, 179-199. doi:10.1080/09243450600565795

Schmitz, G. S., \& Schwarzer, R. (1999). Proaktive einstellung von lehrern: Konstruktbeschreibung und psychometrische analysen (teachers' proactive attitude: Construct description and psychometric analyses). Zeitschrift für Empirische Pädagogik, 13, 3-27.

Schutz, P. A., \& DeCuir, J. T. (2002). Inquiry on emotions in education. Educational Psychologist, 37, 125-134. doi:10.1207/S15326985EP3702 7

Schutz, P. A., \& Lenehart, S. J. (2002). Emotions in education. Educational Psychologist, 37, 67-78. doi:10.1207/S15326985EP3702_1

Schutz, P. A., Hong, J. Y., Cross, D. I., \& Osbon, J. N. (2006). Reflections on investigating emotions among educational contexts. Educational Psychology Review, 18, 343-360. doi: 10.1007/s10648-006-9030-3

Schwarzer, R., \& Hallum, S. (2008). Perceived teacher self-efficacy as a predictor of job stress and burnout: Mediation analysis. Applied Psychology: An International Review, 57, 152-171. doi:10.1111/j.1464-0597.2008.00359.x

Seligman, M. E. P. (2002). Authentic happiness: Using the new positive psychology to realise your potential for lasting fulfilment. New York: Free Press. 
Skaalvik, E. M., \& Bong, M. (2005). Self-concept and self-efficacy revisited: A few notable differences and important similarities. In H. W. Marsh, R. G. Craven, \& D. M. McInerney (Eds.), International advances in self research Vol. I (pp. 67-89). Greenwich: Information Age Publishing.

Skaalvik, E. M., \& Skaalvik, S. (2007). Dimensions of teacher selfefficacy and relations with strain factors, perceived collective teacher efficacy, and teacher burnout. Journal of Educational Psychology, 99, 611-625. doi:10.1037/0022-0663.99.3.611

Smith, A., Kendal, L., \& Hulin, C. (1969). The measurement of satisfaction in work and retirement: A strategy for the study of attitude. Chicago: Rand McNaily.

Somech, A., \& Drach-Zahavy, A. (2000). Understanding extra-role behavior in schools: The relationships between job satisfaction, sense of efficacy, and teachers' extra-role behavior. Teacher and Teacher Education, 16, 649-659. doi:10.1016/S0742-051X(00)00012-3

Stajkovic, A. D., \& Lee, D. C. (2002). A meta-analysis of the relationship between collective efficacy and group performance. Unpublished manuscript.

Stephanou, G. (2004). Effects of ability self-perception, perceived taskdifficulty, performance expectations and importance of performance on performance and attributions in specific academic domains. In J. Baumert, H. W. Marsh, U. Trautwein, \& G. E. Richards (Eds), Proceedings of the 3rd International SELF Research Conference: SelfConcept, Motivation and Identity (CD form). Berlin: Max Planck Institute for Human Development.

Stephanou, G. (2011). Students' classroom emotions: Cognitive antecedents and school performance. Electronic Journal of Research in Educational Psychology, 9, 5-48.

Stephanou, G., Kariotoglou, P., \& Ntinas, K. (2011). University students' emotions in lectures: The effect of competence beliefs, value beliefs and perceived task-difficulty, and the impact on academic performance. International Journal of Learning, 18, 45-72.

Stephanou, G., \& Mastora, M. (in press). Teachers' attributions and emotions for their teaching over a kindergarten year. International Journal of Advances in Psychology.

Stephanou, G, \& Sivropoulou, E. (2008). Kindergarten teachers' selfefficacy and attributions for positive and negative classroom situations. 10th International Congress of Balkan Society for Pedagogy and Education: Further Education in the Balkan Countries. Konya: Selcuk University.

Stephanou, G., \& Tsapakidou, A. (2007a). Socio-cognitive antecedents of teacher motivation. In Y. Theodorakis, M. Goudas, \& A. Papaioannou (Eds.), Proceedings of the12th European Congress of Sport Psychology, Sport and Exercise Psychology. Bridges between Disciplines and Culture. Halkidiki: University of Thessaly \& European Federation of Sport Psychology, 248-252.

Stephanou, G., \& Tsapakidou, A. (2007b). Teachers' teaching styles and self-efficacy in physical education. International Journal of Learning, 14, 1-12.

Summers, J. E., \& Davis, H. A. (2006). Introduction: The interpersonal contexts of teaching, motivation, and learning. The Elementary School Journal: Special Issue on the Interpersonal Contexts of Motivation and Learning, 106, 189-192. doi:10.1086/501482

Sutton, R. E. (2000). The emotional experience of teachers. Annual Meeting of the American Educational Research Association. New Orleans, LA.

Sutton, R. E. (2004). Emotion regulation goals and strategies. Social Psychology of Education, 7, 379-398. doi:10.1007/s11218-004-4229-y

Sutton, R. E., \& Mudrey-Camino, R. (2003). The relationship among teachers' emotional intensity, emotional regulation and self-efficacy. The Annual Meeting of the American Educational Research Association. New Orleans, LA.

Sutton, R. E., \& Wheatley, K. E. (2003). Teachers' emotions and teaching: A review of the literature and directions for future research. Educational Psychology Review, 15, 327-358.

doi:10.1023/A:1026131715856

Sy, T., Tram, S., \& O'Hara, L. A. (2006). Relation of employee and manager emotional intelligence to job satisfaction and performance.
Journal of Vocational Behavior, 68, 461-473. doi:10.1016/j.jvb.2005.10.003

Taxer, J. L., \& Frenzel, A. (2012). The influence of teachers' emotions on students' self-concepts and attributions. International Conference on Motivation. Frankfurt am Main, 28-30 August 2012.

Thomas, J. A., \& Montomery, P. (1998). On becoming good teacher: Reflective practice with regard to children's voices. Journal of Teacher Education, 49, 372-380. doi:10.1177/0022487198049005007

Tschannen-Moran, M., \& Barr, M. (2004). Fostering student learning: The relationship of collective efficacy and student achievement. Leadership and Policy in Schools, 3, 189-209. doi:10.1080/15700760490503706

Tschannen-Moran, M. \& Johnson, D. (2011). Exploring literacy teachers' self-efficacy beliefs: Potential sources at play. Teaching and Teacher Education, 27, 751-761. doi:10.1016/j.tate.2010.12.005

Tschannen-Moran, M., \& Woolfolk Hoy, A. (2001). Teacher efficacy: Cap- turing an elusive construct. Teaching and Teacher Education, 17, 783-805. doi:10.1016/S0742-051X(01)00036-1

Tschannen-Moran, M., Woolfolk Hoy, A., \& Hoy, W. K. (1998). Teacher efficacy: Its meaning and measure. Review of Educational Research, 68, 202-248.

Tucker, C. M., Porter, T., Reinke, W. M., Herman, K. C., Ivery, P. D., Mack, C. E., \& Jackson, E. S. (2005). Promoting teacher efficacy for working with culturally diverse students. Preventing School Failure, 50, 29-34. doi:10.3200/PSFL.50.1.29-34

Turner, J. C., Midgey, C., Meyer, D. K., Gheen, M., Anderman, E. M., $\&$ Kang, Y. (2002). The classroom environment and students' reports of avoidance strategies in mathematics: A multi-method study. Journal of Educational Psychology, 94, 88-106. doi:10.1037/0022-0663.94.1.88

Turner, J. C., Meyer, D. K., Midgley, C. \& Patrick. H. (2003). Teacher discourse and sixth graders' reported affect and achievement behaviors in two mastery/high performance mathematics classrooms. Elementary School Journal, 103, 537-582. doi:10.1086/499731

Turner, J. C., \& Schallert, D. L. (2001). Expectancy-value relationships of shame reactions and shame resiliency. Journal of Educational Psychology, 93, 320-329. doi:10.1037/0022-0663.93.2.320

Vauras, M., Salonen, Lehtinen, P., \& Kinnunen, R. (2009). Motivation in school from contextual and longitudinal perspectives. In M. Wosnitza, S. A. Karabenick, A. Efklides, \& P. Nenniger (Eds.), Contemporary motivation research: From global to local perspectives (pp. 1-23). Cambridge: Hogrefe \& Huber.

Weiner, B. (1992). Human motivation: Metaphors, theories and research. London: Sage.

Weiner, B. (2001). Intrapersonal and interpersonal theories of motivetion from an attributional perspective. Educational Psychology Review, 12, 1-14. doi:10.1023/A:1009017532121

Weiner, B. (2005). Motivation from an attributional perspective and the social psychology of perceived competence. In A. J. Elliot, \& C. S. Dweck (Eds.), Handbook of competence and motivation (pp. 73-84). New York: Guilford.

Wentzel, K. R. (1996). Social goals and social relationships as motivators of school adjustment. In J. Juvonen and K. R. Wentzel (Eds.), Social motivation: Understanding children's school adjustment (pp. 226-247). Cambridge: University Press. doi:10.1017/CBO9780511571190.012

Wheatley, K. F. (2005). The case for reconceptualizing teacher efficacy research. Teaching and Teacher Education, 21, 747-766. doi:10.1016/j.tate.2005.05.009

Woolfolk Hoy, A., \& Davis, H. (2005). Teachers' sense of efficacy and adolescent achievement. In T. Urdan, \& F. Pajares (Eds.), Adolescence and education: Vol. 5: Self-efficacy beliefs during adolescence (pp. 117-137). Greenwich, CT: Information Age.

Wolters, C. A., \& Daugherty, S. G. (2007). Goal structures and teachers' sense of efficacy: Their relation and association to teaching experience and academic level. Journal of Educational Psychology, 99, 181-193. doi:10.1037/0022-0663.99.1.181

Wong, C. A., \& Dornbusch, S. M. (2000). Adolescent engagement in school and problems behaviors: The role of perceived teacher caring. The Annual Meeting of the American Educational Research Associa- 


\section{G. STEPHANOU ET AL.}

tion. New Orleans, LA.

Yoon, J. S. (2002). Teacher characteristics as predictors of teacherstudent relationships: Stress, negative affect, and self-efficacy. Social Behavior and Personality, 30, 485-493.

doi:10.2224/sbp.2002.30.5.485
Zimmerman, B. J., \& Kitsantas, A. (1999). Acquiring writing revision skill: Shifting from process to outcome self-regulatory goals. Journal of Educational Psychology, 91, 241-250.

doi:10.1037/0022-0663.91.2.241 